\title{
Differentiated Instructional Strategies and Assistive Technology in Brazil: Are We Talking about the Same Subject?
}

\author{
Gerusa Ferreira Lourenco*, Adriana Garcia Goncalves, Nassim Chamel Elias \\ Department of Occupational Therapy, Federal University of São Carlos, Brazil
}

Copyright (C) 2015 by authors, all rights reserved. Authors agree that this article remains permanently open access under the terms of the Creative Commons Attribution License 4.0 International License

\begin{abstract}
The aim of this study was to present the association of educational strategies and differentiated instructions with assistive technology for special education students. The use of technology is an important ally for mediation among teachers, students and academic content. For special education students, there is a need to promote general adjustments, such as architectural, curricula and material adaptations. Among the technological possibilities, assistive technology has gained prominence in order to provide functional improvement and success in performance by people with disabilities. The potential participation achieved by using a resource properly implemented makes this theme present in educational policies aiming the inclusive education, permeating the need for the teacher to make use of these resources when teaching these students. However, by just having the resource available does not guarantee that it will benefit learning, it is necessary to introduce differentiated instruction strategies, because each student's specific needs must be considered. Teachers who use differentiated instruction are quite aware of the goal they want to achieve and the curriculum sequence defined by the governing bodies of education, and care about the education and learning of academic content with the necessary adaptations for special education students. They are aware that students are at different skill levels, but in a continuous understanding and development. The main goal of assistive technology, associated with the applicability of appropriate strategies, is to maximize the skills of each student by teaching and helping him/her to develop it as much and as quickly as he/she can. Once the skills are acquired, they enhance learning for these students because they make accessibility to content easier and make the learning enjoyable.
\end{abstract}

Keywords Special Education, Inclusion, Assistive Technology, Differentiated Instruction, Teaching Strategies

\section{Introduction}

The technology follows human evolution according to the demands and requirements that the environment imposes for survival and continuity of the human species. Thus, the technological development of each period marked the culture and the way of understanding its history and thereby the technology alters human behavior. In other words, technology defines the man of the day.

In the school classrooms context, academic content are determined by the curricula defined according to social, political, and ideological demands related to information and functional capabilities for a person to be active and productive in the society. The use of technology is an important ally for mediating teachers' actions, students' performances, and the contents to be taught.

The movement for the right to education and, more specifically, for the inclusion of special education students in the regular classroom, has strengthened in the last decade in Brazil. Policies were restructured to organize potential services and practices to provide access and permanence of these students in regular schools. The Policy of Special Education in the Perspective of Inclusive Education[1] guides the need for special educational services and resources to support, complement, and supplement the regular educational services, to provide trained and expert faculty, curriculum flexibilizations, and use of specific teaching methodologies, providing resources, special materials, and accessibility.

Therefore, the presence of special educators in regular schools has a special spot in the Multifunctional Resource Classrooms, aiming to support the organization and provision of Specialized Educational Support (SEA). SEA is provided in complementary or supplementary form to students with disabilities and autism spectrum disorders, and gifted students enrolled in regular schools, ensuring conditions of mobility, participation, and learning[2]. 
The current Brazilian policy corroborates findings in the literature regarding the potential implementation of differentiated resources with the goal of providing equal learning opportunities to all students, and states their use by teachers working with specialized educational interventions.

Multiple distinct teaching and instructional strategies should be part of the teacher's routine in the classroom, in order to allow access and success for all students' learning process. In addition, beyond these teaching resources, the use of technological resources has gained voice in the country, towards the specific demands of students' participation in any given activity.

With regard to special education students, there is a need to promote general adjustments, such as architectural adaptations, and more specific adjustments, such as curricula and material adaptations. The literature confirms that in order to provide the effective educational services to special education children it may be necessary to implement assistive technology resources as well as augmentative and alternative communication systems, appropriate furniture, physical spaces and teaching aids oriented to the development of their capabilities.

Among the available technological possibilities, assistive technology has gained prominence in order to provide functional improvement and success in the completion of activities by people with disabilities. In this sense, the Assistive Technology, as a knowledge area that involves many resources, equipment, strategies and methodologies aiming at improving the functionality of people with disabilities[3], is gradually more current in the educational context.

Assistive technology resources are an efficient tool for access to the curriculum when properly implemented, and their use has been greatly encouraged worldwide and, more recently, in Brazil for the teaching of special education students $[1,4]$. Thus, Brazil is beginning a movement of theoretical definition and service organization by political entities seeking to deliver these resources effectively to the interested population. Laws and decrees are being formulated with the aim of establishing action targets for these resources in Brazil, and their use in the educational context has gained prominence.

As an example, it is worthy to cite the Brazilian National Plan on the Rights of People with Disabilities: Live without Limits [5], established by Decree 7.612 of November $17^{\circ}$, 2011, which ratifies Brazil's commitment to the UN Convention prerogatives on the rights of people with disabilities. Regarding the Assistive Technology, the document indicates that, from 2011 to 2014, some goals should be achieved, as the implementation of the Brazilian National Program for Assistive Technology for creating economic support and refundable grant funding for assistive technology innovation and for Paralympic sports equipment.

The use of assistive technology in certain areas and activities, such as daily life activities, establishment of effective communication, and participation in the classroom and accessibility to learning materials should be prioritized.
The assistive technology may help children deprived of experiences offered to other children and unable to handle teaching/learning materials and to respond the way other children do, due to their functional differentiated conditions [6].

The properly implementation and use of assistive technology resources will allow a better participation of special education students in many contexts. Due to this potential, this theme is part of the educational policies concerning the inclusive education scenario.

Specifically, regarding the services in Brazil, Multifunctional Resource Rooms are highlighted as an area for different strategies, equipment and instructions to be planned and executed in regular schools. Therefore, with a view to the quality of these interventions, the Brazilian guiding document [7] suggests that Specialized Educational Support teachers have a list of responsibilities. This list includes: development, implementation and evaluation of the student's support plan; setting the student's schedule and activities; teaching strategy organization and accessible resources identification and production; teaching and development of Specialized Educational Support activities, such as Brazilian Sign Language (LIBRAS), Braille, guidance and mobility, Portuguese for deaf students; accessible computers; Alternative and Augmentative Communication (AAC); activities to develop superior mental skills and curriculum enrichment activities; monitoring the functionality and usability of assistive technology resources in the regular classroom and other school settings; interaction with teachers of regular classes in the different stages and modalities of teaching; guidance to regular education teachers and families on the applicability and functionality of the resources used by the student; interface with the areas of health, care, work and others [7].

There are many tasks for the special education teacher when assistive technology resources are present for both the education and development of activities that take place in the specialized educational class, and the use and monitoring of these resources in other school settings such as the regular classroom, cafeteria, and playground, among others.

However, in everyday practice and on spaces of knowledge production, an issue has gained outline as to understanding how to mediate the use of assistive technology resources, the use of teaching technologies and strategies in special education child's daily life. According to Dell, Newton, and Peroff [8], the main obstacle to the implementation of assistive technology resources at school is the lack of knowledge and specific skills of educational professionals.

An inaccuracy of definitions and concepts for each of these subjects has brought confusion to teachers and school community about what is the real role of these actions in the school context. Would they be synonymous in the school context?

Therefore, the aim of this study is to present the relationship between teaching strategies and instruction with the use of assistive technology for special education students, 
considering inclusive schooling.

\section{Method}

This research focuses on the qualitative approach to the Grounded Theory method. According to Brantlinger et al.[9], this type of method develops a research to generate or discover a general theory or an abstract analytical hypothesis based on the study of a phenomenon in a particular situation.

Charmaz [10], based on Glaser and Strauss [11, 12] cites the factors in the grounded theory:

- Simultaneous involvement in the data collection and analysis;

- Building codes and analytical categories based on the data, and not from preconceived and logically deduced hypothesis;

- Using the constant comparative method, which comprises the elaboration of comparisons during each stage of analysis;

- Progress in the development of the theory in every step of the data collection and analysis;

- The drafting of memoranda to develop categories, specify their properties, determine relationships among categories and identify gaps;

- Sampling directed to the construction of the theory, rather than for the population representation [10].

There are several methods used as tools for data collection on grounded theory to provide cleared instruments to generate, remove and produce sense of the data.

The concepts constructed in the light of grounded theory are considered abstract since they do not depend on time and space. The concept abstraction level or the researcher's ability to abstract the relations among the concepts determines the theoretical dimension. When the researcher describes the relationships among concepts, he/she establishes the components in the concepts or in the itemized categories to study the concepts.

Thus, the phenomenon investigated here relates teaching strategies and instruction with the use of assistive technology in the inclusive school context. Data analysis was done through the interrelation and description of terms relevant to the understanding of teaching strategies, instruction, and assistive technology.

\section{Results and Discussion}

The results show the understanding of assistive technology and its interrelationships with concepts of instrumental mediation, teaching strategies and directions, according to the reality of teaching practices in Brazil.

\section{Assistive Technology: Concepts and Instrumental Mediation}

The motivation to use resources and new methodologies brought the need for teachers to review their practices in order to encompass different teaching and instructional strategies to produce the equalization of opportunities and participation for special education students.

However, as pointed out by Dalton [13], a proposal for the effective integration of technology in an educational system must include components of technology, professional development of educators, student's individualized planning, integration between technology and curriculum, the presence of a technical professional board, students and families, results evaluation and impacts presented by the student in the activities, organizing initiatives for technology assessment, ways of providing and maintaining the resource, institutional changes, and integration of assistive technology training in special education teachers' training programs.

The school must undergo changes so that inclusive education policies become real, such as shifting from a traditional model of education that emphasizes pre-established patterns to valorize initiatives that embrace differences in order to enhance students' current skills. The differences should not be seen as conditions of greater or lesser disadvantages facing the interactions with the environment, but as a factor of development of a society that lives in diversity and collectively.

Assistive technology is conceptualized as an interdisciplinary area that aims to ensure functionality and participation in performing an activity by people with disabilities or reduced mobility. To accomplish that, the assistive technology provides resources, equipment, products, methodologies, strategies, practices, and services to promote autonomy, independence, quality of life, and social inclusion [3].

It is noted that the concept of assistive technology is very broad because many resources, mainly related to health in the context of rehabilitation, were being called assistive technology such as an electrotherapy device that minimizes inflammatory and painful processes, ensuring better functionality for people with reduced mobility. However, these devices are used by the professionals and thus are their working tools, excluding them as assistive technology resources. Thus, it is understood that the assistive technology should be used by the person with disabilities or reduced mobility in all social environments to provide autonomy and social participation and not just during the rehabilitation session, as in the previous example.

Nevertheless, how does one indicate the assistive technology in the school context? Can teaching strategies be referred to as assistive technology? Special education teachers, through the specialized educational service planning offered to special education students, must introduce the use of technology coupled with curriculum contents and not in isolation and out of context as it generally occurs in current everyday school practice.

However, by just having the resource available in classroom does not guarantee that it will benefit special education student's learning; it is necessary to introduce 
differentiated instruction strategies to carry out the activity, because each student has specific needs that must be met. Manzini [14] defines strategy as a teacher's action to meet the educational goals.

Gasparetto et al. [15] indicated that the assistive technology resources and equipment presented in schools are still incipient and, when present, few teachers had sufficient knowledge of how to use the resources with students with disabilities.

According to Galvão Filho [16] the assistive technology represents a way to search for "alternative routes" for the construction of knowledge by people with disabilities. The author uses the term instrumental mediation, to refer to the use of assistive technology to assign meaning to the phenomena that takes place in the environment, and so the person will intervene in this environment more functionally. Assistive technology enables development and learning of people with disability from the moment it favors and stimulates the creation of new ways and possibilities for the person to interact with the environment and with the objects that surround it, guaranteeing accessibility and autonomy.

Beyond this instrumental mediation, it is noteworthy that every instrument, before incorporated in one's routine, must go through a testing process, by being tried by the person and, when necessary, go through the process of adaptation considering the evolution of the use and the changes this use will provide to the person. Therefore, development of relevant teaching strategies is vital in relation to this appropriation of instrumental mediation in the educational context for students with disability.

\section{Teaching Strategies and Instructions with the Use of Assistive Technology}

When using educational strategies to facilitate student's participation, for example, in the case of establishing alternative communication, the teacher must develop strategies for the students to reach the resource and point or look at symbols or pictures, as well as category photographs that are part of the student's routine, starting with photos of classmates, teachers, and items in the classroom.

Thus, teaching strategies are defined as the actions that the teacher plans and performs, detailing all the possible responses the student may present according to the subject he/she is learning. The teacher, throughout their teaching practice, uses teaching strategies, regardless the use of assistive technology. Therefore, the opposite is not true. For the implementation and use of assistive technology resources to occur successfully, it is essential the construction of strategies and differentiated instructions by the teacher.

Teachers who use differentiated instructions are quite aware of the goal they want to achieve and of the curriculum sequence defined by the governing bodies of education, and care about academic content teaching and learning with the necessary adaptations for special education students. They are aware that students are at different skill levels, but in a continuous learning of novel skills. The main goal of assistive technology, associated with the applicability of appropriate strategies, is to maximize the skills of each student by teaching and helping him/her to develop and use it as much and as quickly as he/she can.

When a teacher chooses the resource, he/she should consider the best teaching strategies such as better positioning of the resource on the table, and student's response latency or reaction time. Furthermore, it is important that the teacher thinks about differentiated instruction that will be used with the student (verbal, physical, and/or sensory), because teacher's assignments go from organizing teaching strategies to producing accessible resources.

Galvão Filho [17] questions whether there is an educational assistive technology that can drive the learning and develop cognitive functions of students with disabilities.

"For example, currently, different educational software found in the market call themselves "Assistive Technology for learning," or for literacy of children and adolescents with Down Syndrome. So, when considering the content in these software, which address themselves as "specific assistive technology to the learning of children with Down Syndrome", invariably, one finds only ordinary activities related to the development of memory (e.g., memory games), activities related to perception and discrimination of colors and shapes or exercises with numbers, letters, syllables, and words. Activities that have nothing specific to do with the world of Down Syndrome" [17: 32 [authors' free translation]].

On the other hand, the author points out that the difficulties related to motor, visual, auditory, or communication functions can be minimized when assistive technology is introduced in order to improve functionality, promoting involvement in an activity performed by the person with disabilities. There are, for example, alternative communication software that enables communication to non-vocal students and voice synthesizer software to promote access to information for blind students. Any equipment, product and feature that brings accessibility to the person with disabilities in implementing an activity may be considered assistive technology. Thus, the assistive technology resources might meet individual demands to ensure participation and autonomy.

However, if the assistive technology meets an individual demand to ensure autonomy and social participation, in order to allow functionality to daily activities, it means that assistive technology has its applicability to individuals with intellectual disabilities and difficulty in learning specific contents or concepts, opposing Galvão Filho's [17] conception. As an example, knowing that a student has difficulty in associating and discriminating the quantity based on a written number (logical-mathematical cognitive function) and that the student knows how and prefers to use deck of cards, the cards can be adapted (keep only the number and the amount of suit drawings indicated in the card). This way, the adapted resource will be used by the student to ensure autonomy and participation in performing 
school activities. A deck of cards with quantity information in Braille is considered an assistive technology resource for a blind person.

To summarize, to determine what is or is not assistive technology will depend on whether the use of the resource, equipment or product will bring functionality to the activity in order to guarantee acquisition of knowledge, skills and autonomy for the student to learn in the school context.

\section{The Role of the School Support Team}

The special education teachers must have knowledge and skills to make decisions about selection, use and evaluation of technology resources to implement them properly [18]. Specifically in the school context and according to the policy of including special education students in regular classrooms, one way to encourage more assertive practices of real integration of different resources has been the business among various professionals.

To work with special education students, the first step is to go through a proper system of educational needs evaluation to determine which are the adaptations and technological resources that need to be implemented for each student. To do so, it is essential to rely on skilled professionals, who know how to evaluate these demands and lead these students to their maximum development, without assigning extra responsibility for the entire process only to the regular classroom teacher [19]. Regular classroom teachers, multi-functional resource classroom teachers and professionals in health and education areas such as occupational therapists and special education teachers may work collaboratively to stablish the real needs of students with disabilities and ensure success with teaching-learning quality, selecting the best available resources and strategies.

According to Mendes [20] and Capellini [21], the main objectives for teamwork is to improve effectiveness and increase the degree of job satisfaction, once teamwork is an strategy produced by the man himself. These authors point out that collaboration is a very successful teamwork approach. However, the challenge that arises is in order to equate the roles and knowledge of each professional in attending the student, as differentiated work dynamics, preference for individual work and interactions only from a hierarchical relationship can compromise the formation of collaborative partnerships, especially between special and regular education settings [20].

Therefore, it is imperative to have a team support for all the early stages of construction and implementation of assistive technology resource as well as for the later stages of monitoring, testing, adjustments, and customization of the resource. The whole process is essential so that the successful use is reached and the assistive technology resource is not abandoned.

\section{Conclusions}

Considering the need for the use of different strategies to teach special education students in inclusive classrooms, assistive technology is a theme present in policy and educational practices. However, the question that arises is the importance of providing and mediating a variety of instructions and strategies by the teacher, even when these resources are available in the classroom.

The inclusion of special education students in regular classrooms may be understood as a bidirectional process that includes, on one hand, the manifestation of the needs of the special education student and, on the other hand, the implementation of adjustments and actions needed to allow access and sharing a common, not segregated, space.

In the school context, all types of support (personal, physical, material, equipment) should be available to the students in order to allow them accessibility and functioning in the community. Also in the school context, assistive technology resources should be used to maximize students' skills and, through educational planning based on strategies and differentiated instruction, to allow accessibility to the curriculum and quality of the teaching-learning process. Therefore, there must be a strong interrelationship between differentiated teaching instructions and strategies and Assistive Technology.

\section{REFERENCES}

[1] BRASIL Política Nacional de Educação Especial na Perspectiva da Educação Inclusiva.2008. Retrieved from http://portal.mec.gov.br/dmdocuments/rceb004_09.pdf. .

[2] BRASIL Resolução $n^{\circ} 4$ de 2 de outubro de 2009: Institui as Diretrizes operacionais para o Atendimento Educacional Especializado na Educação Básica, modalidade Educação Especial.2009. Retrived from

http://portal.mec.gov.br/dmdocuments/rceb004_09.pdf

[3] BRASIL. Ata da Reunião VII, de dezembro de 2007. Comitê de Ajudas Técnicas. Secretaria Especial dos Direitos Humanos da Presidência da República (CORDE/SEDH/PR), 2007. Retrieved from

$<$ http://www.mj.gov.br/corde/arquivos/doc/Ata_VII Reuniã o_do_Comite_de_Ajudas_Técnicas.doc $>$

[4] Okolo, C. M. \& Bouck, E. C.. Research about assistive technology: 2000-2006: what have we learned? Journal of Special Education Technology, 2007, 22: 19-33.

[5] BRASIL. Plano Nacional dos Direitos da Pessoa com Deficiencia: Viver sem Limite. Secretaria de Direitos Humanos da Presidência da República (SDH/PR) / Secretaria Nacional de Promoção dos Direitos da Pessoa com Deficiência (SNPD). 2013.

[6] Gargiulo, R. M. Special education in contemporary society: an introduction to exceptionality. Belmont (CA): Wadsworth / Thomson Learning, 2006. 
de Salas de Recursos Multifuncionais. Brasília: MEC, SECADI, Diretoria de Políticas de Educação Especial. 2012.

[8] Dell, A. G., Newton, D. A., Petroff, J. G. Assistive technology in the classroom: enhancing the school experiences of students with disabilities. New Jersey: Pearson Education Inc; 2008.

[9] Brantlinger, E., Jimenez, R., Klingner, J., Pugach, M., \& Richardson, V. Qualitative Studies in Special Education. Exceptional Children. 2005; (71): 195-207.

[10] Charmaz, K. A. Construção da Teoria Fundamentada: guia prático para análise qualitativa. Porto Alegre, RS: Artmed; 2009.

[11] Glaser, B. G. \& Strauss, A. L. The Discovery of Grounded Theory. Chicago: Aldine, 1967.

[12] Glaser, B. G. \& Strauss, A. L. Status Passage: A Formal Theory. Chicago: Aldine, 1970.

[13] Dalton, E. M. Assistive technology in education: a review of policies, standards, and curriculum integration from 1997 through 2000 involving assistive technology and the Individuals with Disabilities Education Act. Issues in Teaching and Learning, 2002(1).

[14] Manzini, E. J. Recurso pedagógico adaptado e estratégias para o ensino de alunos com deficiência física. In: Manzini, E.J.; Fujisawa, D.S. (orgs). Jogos e recursos para a comunicação e ensino na educação especial. Marília: APPEE, 2010, p. 111131.

[15] Gasparetto, M. E. R. F., Maia, S. R., Manzini, E. J., Maior, I., do Nascimento, F. C., Miranda, J. R., Ramos, C. R., dos Santos, M. C. D., Carvalho, V., \& Barbosa, K. M.. Uso de recursos e equipamentos de Tecnologia Assistiva na educação municipal, estadual e federal tecnológica. In: BRASIL.
Subsecretaria Nacional de Promoção dos Direitos da Pessoa com Deficiência. Comitê de Ajudas Técnicas - CAT. Brasília. CORDE, 2009.

[16] Galvão Filho, T. A. Tecnologia assistiva: favorecendo o desenvolvimento e a aprendizagem em contextos educacionais inclusivos. In: Giroto, C.R.M.; Poker, R.B.; Omote, S. (orgs.). As tecnologias nas práticas pedagógicas inclusivas. Marília: Oficina Universitária; São Paulo: Cultura Acadêmica, 2012, p. 65-92.

[17] Galvão Filho, T. A. A construção do conceito de Tecnologia Assistiva: alguns novos interrogantes e desafios. Revista da FACED - Entreideias: Educação, Cultura e Sociedade, 2013; 2(1): 25-42.

[18] Lahm, E. A. \& Sizemore, L. Factors that influence assistive technology decision-making. Journal of Special Education Technology, 2002, 17: 15-25.

[19] Lourenço, G. F. Avaliação de um programa de formação sobre recursos de alta tecnologia assistiva e escolarização. [Doutorado em Educação Especial - Educação do Indivíduo Especial]. São Carlos, Universidade Federal de São Carlos; 2012.

[20] Mendes, E. G.. Colaboração entre ensino regular e especial: o caminho do desenvolvimento pessoal para a inclusão escolar. In: Manzini, E. J. (Org.). Inclusão e acessibilidade. Marília: ABPEE, 2006. p. 29-41.

[21] Capellini, V. L. M. F. Avaliação das possibilidades do ensino colaborativo no processo de inclusão escolar do aluno com deficiência mental. [Doutorado em Educação Especial]. São Carlos, Universidade Federal de São Carlos; 2004. 